\title{
"THE COMMERCIAL LAW OF MALAYSIA"* - REVISITED SECTION 5(2) OF THE CIVIL LAW ACT 1956; CONSTITUTIONALITY, THE EU AND ISLAMISATION
}

\author{
Baharuddeen Abu Bakar**
}

\begin{abstract}
Sec. 5(2) of the Civil Law Act 1956 with its predecessors, providing for the application of English commercial law of Malaysia, have existed unaltered for more than 100 years even with revision. There have been important political and economic developments during this period: Independence; the Malaysian Constitution; UK's entry into the EU bringing with it the question of the constitutionality of applying English legislation and EU commercial legislation in independent Malaysia; and the attempt to found Malaysian civil law on Islamic values and
\end{abstract}

Title of a series of articles by Prof. Bartholomew, later published as a monograph by the Malayan Law Journal, Singapore in 1965. The monograph is the text referred to in this article.

LL.B Hons (Univ. Malaya); Diploma in Sharia Law and Practice, Master in Comparative Law (IIUM); (Non-practising) Advocate and Solicitor of the High Court of Malaya; Senior Lecturer, Legal Practice Department, Ahmad Ibrahim Kulliyyah of Laws (AIKOL), IIUM.

I wish to dedicate this article to Prof. Ahmad Ibrahim who imparted to me and my classmates, the first group of graduates (Class of '76) our first knowledge of Malaysian civil law (and instilled among the Muslim law undergraduates our interest in Islamic law) as the founding dean 
ethics. Singapore has had to make drastic changes to its Civil Law Act, which it finally repealed and introduced a new legislation. The article considers the provision in light of these developments avoiding the well-known problems of interpretation.

Keywords: English commercial law in Malaysia; EU law in Malaysia; constitutionality of sec. 5(2); Islamic commercial values.

\title{
“THE COMMERCIAL LAW OF MALAYSIA" - DILAWAT SEMULA SEKSYEN 5(2) AKTA UNDANG-UNDANG SIVIL 1956; KEPERLEMBAGAAN, EU DAN ISLAMISASI
}

\begin{abstract}
ABSTRAK
Seksyen 5(2) Akta Undang-Undang Sivil 1956 dan peruntukan terdahulu yang digantinya, yang memperuntukkan penerimapakaian undang-undang komersil Inggeris di Malaysia, telah wujud selama lebih 100 tahun tanpa ditukar, mahupun disemak.
\end{abstract}

of the Law Faculty in Universiti Malaya, and introduced us to the Civil Law Act as part of the Malaysian Legal System course, where the scope of its section 5 perplexed me and still does!

I wish to thank my colleagues in AIKOL former Adjunct Prof. Pawancheek Merican, former Senior Academic Fellow Abu Haniffa, former Prof Ali Matta and Assoc Prof. Farid Suffian, for reading this article in draft and making valuable comments and criticisms. The remaining mistakes are mine.

Most of all, I am indebted to Michael F. Rutter, formerly of the National University of Singapore, for the exhaustive treatment of the subject in his book

'The Applicable Law of Singapore and Malaysia,' especially Chap. 5, which relieved me of most of the research work mainly about the Singapore situation and for the thorough discussion of the cases which attempted to interpret the provision. 
Banyak perkembangan penting politik dan ekonomi sepanjang tempoh ini: Kemerdekaan; Perlembagaan Malaysia; kemasukan UK ke dalam EU yang membawa kepada persoalan keperlembagaan menerimapakai perundangan Inggeris dan perundangan komersil EU di Malaysia yang merdeka; dan cubaan untuk mengasaskan undang-undang sivil Malaysia pada nilai dan etika Islam. Singapura telah terpaksa melakukan perubahan mendadak kepada Akta Undang-Undang Sivil; ia akhirnya memansuhkannya dan memperkenalkan sebuah perundangan baru. Makalah ini mempertimbangkan peruntukan tersebut berdasarkan perkembanganperkembangan ini, tetapi mengelak daripada melakukan tafsiran.

Kata kunci: undang-undang komersil Inggeris di Malaysia, undangundang EU di Malaysia, keperlembagaan seksyen 5(2), nilai komersil Islam.

\section{INTRODUCTION}

Few written law provisions have caused as much difficulty in Malaysia (and in Singapore, its equivalent) ${ }^{1}$ as subsection 2 of sec. 5 of the Civil Law Act 1956. It has been nearly 40 years since the appearance of Prof. Bartholomew's ${ }^{2}$ monograph on that provision, and it may be appropriate to revisit the subject in light of the Federal Constitution, which he refers to in passing, ${ }^{3}$ and subsequent legal, political and economic

$1 \quad$ It was sec. 6 of the Civil Law Ordinance No. IV of 1878; re-enacted several times, and until 1965, it was sec. 5 of the Civil Law Act Cap 43 (Singapore Statutes, 1985 Rev. 1985). Except for the reference to the states, it was word-for- word the same as the Malaysian provision.

2 At the time he wrote it, Prof. Bartholomew was a senior law lecturer in the National University of Singapore.

3 Prof. G.W Bartholomew, The Commercial Law of Malaysia: A Study in the Reception of English Law, Malayan Law Journal, 1965 at 43, where he states that the problem of inconsistency arises by reason of the 
developments which, of course, he could not have dealt with. When Prof. Bartholomew wrote his seminal work, his concern was almost exclusively with the interpretation of section 5 (and, to a lesser extent, section 3) of the Civil Law Ord.1956 because, as he understated, "there (were) problems from ...the introduction of English law as the commercial law of Malaysia," and "the commercial law of the constituents of...Malaysia (was) not uniform." 4

Either because it is now substituted by other discrete legislation on the subject or disregarded or its complexities elided, the provision does not seem to have received much attention from Malaysian lawyers, lawmakers and academics with the notable exception of Prof Ahmad Ibrahim, ${ }^{5}$ (unlike our Singapore ${ }^{6}$ counterparts) and for the last 50 years (since Merdeka) of its more than a century in existence, it has been preserved in a colonial time warp.

The concern of this article, as its title suggests, is with:

1) Whether UK law enacted after the Malaysian Constitution as the law of the "corresponding period" in sec. 5(2) has to be applied by Malacca, Penang, Sabah and Sarawak (the former colonies)?

2) Whether if the law of the corresponding period in sec. 5(2) includes EU law and has also to be applied in the former colonies as part of UK law?

3) Does the Singapore experience and response to the above questions have any lessons for Malaysia?

Federal Constitution being the supreme (civil) law, and he quotes Arts 4 and 75- inconsistency between federal law and state law.

$4 \quad$ Bartholomew, supra n.3, Introduction at 1.

5 Prof. Ahmad Ibrahim, “The Civil Law Ordinance in Malaysia” [1971] 2 MLJ viii; Joseph Chia, “The Reception of English Law under Sections 3 and 5 of the Civil Law Act 1956 (Revised 1972)” [1974] JMCL 42.

6 See Rutter F Michael, The Applicable Law of Singapore and Malaysia, Malayan Law Journal Singapore \& Malaysia, 1989 Bibliographies B at 717 and recently Phang, Andrew Boon Leong, From Foundation to Legacy: The Second Charter of Justice, The Singapore Academy of Law, 2006. 
4) The re-assertion of Islamic law by Muslims as expected would have some influence on the development of the commercial law of Malaysia along with the whole process of the shaping of the Malaysian legal system to suit its inhabitants (who are mainly Muslims) and local circumstances.

\section{PART 1}

\section{THE NEED FOR ENGLISH COMMERCIAL LAW BEFORE INDEPENDENCE}

Commerce being the object of the East India Company (EIC), it would not chance its success on the pre-existing Islamic law, ${ }^{7}$ and other customary laws particularly of the Chinese- these were fine for matters affecting only the various communities. ${ }^{8}$ The three Charters of Justice ${ }^{9}$ had been interpreted to marginalize Islamic law with the exception of personal law that the common law allowed, and to accommodate 'local inhabitants' and the ways of the 'asiatics.' 10 The EIC had to make certain that it could do business locally according to law that it understood and best suited its interests. Needed was a law that allowed all things commerce to be conducted in the same manner, according to law of the corresponding period as an English court would apply; hence the triplelayered emphasis of sec. 6 of the (Straits Settlements) Civil Law

$7 \quad$ In the Goods of Abdullah [1835] 2 Ky. Ec. 8; Fathima v Logan \& Ors. [1871] 1 Ky. 255. See the arguments of the Attorney General of the Straits Settlements.

8 This attitude is reflected in sec. 3 of the Civil Law Act.

91805 for Penang; 1826 for Penang and Singapore; and 1855 principally for Malacca, were too basic to accommodate the legal needs of the fast-developing commerce of the colonies.

10 The contempt of the English was quite unabashed: "Imprisonment no deterrent to Asiatics-Malays" (and other more pejorative comment) wrote Sir George Leith, the Lieutenant- Governor of Penang, in abstract of Chapter 2 Kyshe's Law Reports (1) 1800-1884 (Journal section). It is now acknowledged as an offensive term: The New Oxford Dictionary of English. 
Ordinance, No. 4 of 1878. The provision ensured that the English in Malaysia could deal with their counterparts in Malaysia and in England as if the transactions were negotiated and carried out in England, ${ }^{11}$ achieving a form of 'extraterritoriality' for the transactions of English businessmen.

The difficulties caused by the sweeping provision, which made no exception of domestic commerce, forcing the locals in their midst to trade with one another in transactions to be carried out locally according to English law as it stood at the moment, obviously did not concern the colonials.

An attempt has been made to rationalize the imposition of English commercial law in terms of the 'mercantile law' mindset; the merchants took it with them wherever they went in Europe, and would observe only those laws, whatever the local laws were; in other words 'trade on their terms' only.

The provision, it is also claimed, ensured that there would be no legal vacuum in Malaysia as far as commercial law is concerned (which would be the case if one ignores the preexisting Islamic law). ${ }^{12}$

Uncertainty, caused by court-introduced modifications was also eliminated by not having a proviso for adjustment to 'local circumstances' which it was willing to tolerate in the case of non-commercial matterssec. 3. The modifications that could be made by local law-makers caused it less anxiety as the mainly British local law-makers ${ }^{13}$ could be expected to understand the interests of local British traders hence the inclusion of the proviso with respect to local legislation. It was 'divide and rule' in the legal system: one type of common law amenable to modifications for the asiatics and another type of English law for the English and other local men of commerce allowing no modification.

If the English expected to replicate 'Law Merchant' conditions in Malaysia, Bartholomew's dismissive rejoinder is: “Admittedly, the old distinction between the common law and the law merchant depended upon the concept of the merchant, but after three hundred years of dormancy no such distinction is known today. The concept underlying section 5 , therefore, is that of a distinction which is unknown to the common law and is not provided by the Ordinance” Bartholomew, supra, n.3 at 95 .

12 Supra, n. 7.

13 They were enacted by the Straits Settlements Legislative Council. 


\section{BRIEF HISTORY OF THE STAGES OF IMPOSITION OF ENGLISH COMMERICAL LAW}

For a clear understanding of the question, we need to remind ourselves that Penang and Malacca, and Sabah and Sarawak (and Singapore) were colonies, in contradistinction to the Malay States which were British Protectorates.

English commercial law had been applied on dubious authority from the time Penang came under the control of the East India Company in $1786^{14}$ to the time of the enactment of the Straits Settlements Civil Law Ordinance in 1878. Section 5(2) is among the oldest, extant written law provisions in Malaysia. Adapted from sec. 2 of the Civil Law Ordinance, 1853 of Ceylon (now Sri Lanka), it was introduced as section 6 of the (Straits Settlements) Civil Law Ordinance, No. 4 of $1878 .{ }^{15}$

The written law was enacted simply to serve as the statutory ratification for what had been done until then, and to provide a more secure basis for the E.I.C.'s growing economic interests. In his comments to the Legislative Council of the Straits Settlements, the author of the provision, the Attorney General Thomas Braddel, said that the provision was needed to give a legitimate basis for the application of English caselaw in the colonies as they were being applied as if the English legislation on which they were based were part of the law of the colonies. ${ }^{16}$

In the Malay States, the British had applied their commercial laws initially without any statutory basis; by the initiative of their judges who were interchangeable with those of the Straits Settlements, and by force of habit of their lawyers who practised in both parts. Later with the formation of the Federated Malay States in 1895, they enacted the Civil Law Enactment in 1937 with $12^{\text {th }}$ March 1937 as the cut-off date. As Singapore became economically more important to the British, it was separated from Penang and Melaka in 1946 and had its own Civil Law Ordinance. $^{17}$

\footnotetext{
$14 \quad$ Supra n. 7.

15 It was re-enacted in 1909, 1926 and 1936, as Singapore had ceased to be administered as part of the Straits Settlements.

16 Quoted in Rutter, supra n.6 at 176.

17 Supra, n. 1.
} 
In 1951, after the formation of the Federation of Malaya in 1948, they enacted the Civil Law (Extension) Ordinance 1949 which extended the Civil Law Enactment 1937 to all the Malay States including the former un-federated Malay States, with $31^{\text {st }}$ December 1951 as the cut-off date. It was reenacted, on the eve of Independence as section 5(2) of the Civil Law Ordinance, 1956 to cover Penang and Malacca after they became part of the Federation of Malaya in 1948, and sec. 5(1) was introduced for the first time as a discrete provision for the application of English commercial law in the former Malay States.

When Sabah became a colony in 1946, the position under its Civil Law Ordinance 1938 and, later the Application of Laws Ordinance 1951, was that English common law and legislation on commercial matters applied, to the same extent as in Penang and Malacca. When Sarawak became a colony in 1946, its Application of Laws Ordinance 1949 made English common law and legislation on commercial matters applicable, as in Penang, Malacca and Sabah. These were the legislation of the two states till they joined Malaysia.

With the formation of Malaysia in 1963, the Civil Law Ordinance 1956 was revised in 1972 by the consolidation of the relevant provisions of the Sabah and Sarawak legislation with section 5(2), and extended to the 2 states as the Civil Law Act, 1956 which is the current edition of the legislation. The revised text came into force on $1^{\text {st }}$ April $1972^{18}$ in all parts of Malaysia.

The extension to Sabah and Sarawak of the Civil Law Act 1956 did not bring about any change in their positions under their pre-existing Application of Laws Ordinance 1951, and the Application of Laws Ordinance 1949, respectively which were simply superseded. The position now is that section 5(2) applies to Penang and Malacca, and Sabah and Sarawak.

By means of extensions of the cut-off dates till $5^{\text {th }}$ April 1956 with respect to the Malay States and the ongoing imposition provided under sec. 5(2) with respect to the former colonies, the British ensured that and there was a common English commercial law until the last day-

18 As provided for under sec. 6 (1)(d) Revision of Law Act 1968, this is only the date of coming into force of the revised legislation, not the date of coming into force of the Civil Law Act itself which is the original, unrevised legislation of 1956, see Joseph Chia, supra, n. 5. 
$31^{\text {st }}$ August 1957 -of their political control and thereafter to serve their commercial interests as these did not come to an abrupt end on that political event. ${ }^{19}$ Better than that, as events proved, their law seems to have become entrenched.

\section{OUTLINE OF THE ISSUES AND PROBLEMS IN THE APPLICATION OF THE CIVIL LAW ACT IN THE MALAY STATES, THE PENANG, MALACCA, SABAH AND SARAWAK (FORMER COLONIES) AND SINGAPORE}

The section 5 is headed: "Application of English law in Commercial Matters."20

Sec. 5(1) reads: "In all questions or issues which arise or which have to be decided in the states of West Malaysia other than Malacca and Penang with respect to the law of partnerships, corporations, banks and banking, principal and agents, carriers by sea, land and sea, marine insurance, average, life and fire insurance and with regard to mercantile matters generally, the law to be administered shall be the same as would be administered in England in the like case at the date of the coming into force of this Act... (i.e. $7^{\text {th }}$ April 1956)..., if such question or issue had arisen or had to be decided in England, unless in any case other provision is or shall be made by any written law."21

J.J Puthucheary, Ownership and Control in the Malayan Economy, Donald Moore/Eastern Univ. Press Ltd., Singapore, 1960/Univ. of Malaya Cooperative Bookshop Ltd. Kuala Lumpur, 1979. The book discusses British economic interests in Malaya as they were in 1953 when they dominated in all the mercantile law area listed in sec. 5.

20 'Commercial law' in the heading and 'mercantile law' in the substantive provision must of necessity be taken to mean the same, as 'mercantile law' had been absorbed by the Common Law. See further, Prof. Bartholomew, supra n.1 at .95.

21 Local legislation have in fact been enacted and made applicable to the whole country which reduces the need for English: Partnership Act 1961 (135); Companies Act 1965 (Act 125); (Act 441); (Act 100); (Act 258); Banking and Financial Institutions Act 1989 (372); (Act 202); (Act 9); (Act 146); (Act 571); (Act 33); (Act 204) (Act 519); (Act 443); Principally, Contracts Act, (Part X) 1950 (Act 136); (Act 424); (Act 27); 
5 (2) reads: "In all questions or issues which arise or which have to be decided in the States of Malacca, Penang, Sabah and Sarawak with respect to the law concerning any of the matters referred to in subsection (1), the law to be administered shall be the same as would be administered in England in the like case at the corresponding period, if such question or issue had arisen or had to be decided in England unless in any case other provision is or shall be made by any written law."

Section 5 divides the country into two parts for the purpose of the application of English commercial: the former Malay States with $7^{\text {th }}$ April 1956 as the cut-off date so that English commercial law after that date is not the binding law though it may be applicable and local courts are expected to develop the common law as already applied in the former Malay States and, of course, local legislation; and the former colonies where the application is expected to be continuing to this day and into the future except to the extent that there is other Malaysian legislation. Not only is English commercial legislation binding it has to be applied as it stands on the question to be decided arises and it has to be applied the way an English court would.

The implications of the subsections may be tabulated as follows:

1) There are now two commercial law regimes in Malaysia: one for the former Malay States featuring ‘deadline reception' and one for the former colonies with ongoing reception.

2) In the Malay States and in the former colonies the position was the same till $5^{\text {th }}$ April 1956: sec. 5(1) and sec. 5(2).

3) In the Malay States between the $5^{\text {th }}$ April 1976 and $31^{\text {st }}$ August 1957, English commercial law could be the applicable law and therefore may be applied with suitable modification.

4) After $31^{\text {st }}$ August 1957 it is not clear how English commercial legislation was treated.

Carriage by Air Act, 1974; Road Transport Act 1987 (Act 333); (Act 334); (Act 294); Carriage of Goods by Sea Act 1950 (Act 527); (Ord. 70/ 1952); (Act 15/1956); Insurance Act 1996 (Act 553); (Act 444). 
5) In the former colonies English law was to be the binding source of law, not only that it had to be applied as it stood on the corresponding period to the transaction even if it is today and if it had to be applied it requires Malaysian courts to apply English law, not according to a Malaysian court's understanding, taking into account local circumstances and inhabitants, as in the case of sec. $3^{22}$ but the way an English court would, and this is reinforced: "as if the question or issue had arisen or had to be decided in England”23 i.e. in an 'English setting.'

6) In practice, however, as far as English case law, at least, is concerned the two commercial law regimes seem to have merged. The English legal education of the majority of lawyers in private practice makes for a tendency to readily rely on English caselaw without first considering whether the case-law interprets or applies post cut-off date English legislation which amounts to applying English legislation via case-law.

7) In no part of Malaysia do the courts seem to have considered the status of English commercial legislation vis-à-vis the Constitution after 31 ${ }^{\text {st }}$ August 1957.

Considerable difficulties and controversies have been experienced in Singapore, the Malay States before independence, and continued in the former colonies after Independence. The problems arising from the application of English commercial legislation have been considered by the courts, mainly in Singapore, ${ }^{24}$ and may be summarised as follows:

1) Is there a difference between 'mercantile law' and 'commercial law'?25

$22 \quad$ The proviso to sec. 3 reads: "Provided always that the said common law, rules of equity and statutes of general application shall be applied so far only as the circumstances of the States of Malaysia and their respective inhabitants permit and subject to such qualifications as local circumstances render necessary.”

23 This, by contrast, is not the requirement in sec. 3 Civil Law Act 1956.

24 In chapter 5 of his book, Rutter, supra, n. 6 has given the most exhaustive treatment of the subject.

25 As both 'commercial law' and 'mercantile law' are used in the same 
2) Does the provision apply to all commercial/mercantile matters which are not listed including those compendiously referred to as "mercantile matters generally"?26

3) Is English commercial legislation included in the expression 'law'?27

4) Does the whole of English law become applicable on a subject characterized as commercial? ${ }^{28}$

5) Just what is the English commercial legislation? ${ }^{29}$

provision they should be taken as intended to have the same meaning. However, the Oxford Dictionary of Law makes a distinction "Law merchant" (another term for mercantile law) is defined as: "The international practice of merchants relating to commercial and maritime matters. In early times it influenced Admiralty law and law administered in local courts. Parts of the law merchant were absorbed into the common law of England (e.g. that relating to negotiable instruments and the transfer of bills of lading). This writer takes the view that 'mercantile matters, generally' includes all matters which are the subject-matter of commerce including commercial organizations such as companies so that the tendency of some Malaysian courts to straddle both provisions with their vastly different effects because of their inability to decide may be avoided. The general expression must also be given some meaning and not be treated as surplusage, and to achieve a more consistent result with similar matters which are spelt out. This is particularly so as Malaysia did not amend its Civil Law Act to introduce the delimiting words; 'with respect to those matters.' See Thambipillai $v$ Borneo Motors (M) Ltd [1970] 1 MLJ 70 at 71D, a hire-purchase transaction where both provisions are referred to.

Seng Djit Hin v Nagurdas Purshotamdas \& Co (1921) 14 SSLR 181 per Voules J. at 209. Sockalingam [1933] AC 342 (PC); [1933] 2 MLJ 81.

It is more easy to enumerate those which have been applied or referred to by the courts than to list all such legislation; see further Rutter, supra, n. 6 at 196; See further Hickling for a list of the legislation which may be applicable; S. 5 of the Civil Law Act: Snark or Boojum? (1979) 21 Mal LR 351; Singapore has now spelt out these legislation; $1^{\text {st }}$ Schedule Application of English Law Act 1993 (S'pore). 
6) Can the legislation be applied in the absence of the administrative machinery needed for its compliance and enforcement? ${ }^{30}$

7) Is the whole of English law to be applied as soon as an issue or question is characterised to be mercantile? ${ }^{31}$

8) Is the whole commercial legislation to be applied including those parts which are non- commercial? ${ }^{32}$

9) To what extent is English law excluded by local law or may English law still supplement the gaps in Malaysian law?

10) Does the application of English law to a transaction make it the law for all such transactions i.e. an authority or is the application ad hoc, not binding on other such transactions only 'referred' to? ? $^{33}$

11) Is any modification to suit local circumstances possible?

Before these questions could be resolved came another major upheaval to the commercial law regime of the former colonies, and Singapore.

$30 \quad$ Bajerai $v$ Sockalingam [1933] AC 342 (PC); [1933] 2 MLJ 81; see also, supra, n. 59.

$31 \quad$ Singapore had to amend its sec. 5 to add after law the words; 'with respect to those matters.' Civil Law (Amendment No 2) Act, (24 of 1979).

$32 \quad$ Seng Djit Hin v Nagurdas Purshotamdas \& Co [1923] AC 444.

33 In Singapore a rather recherche view of the application of English law has come about: it is only a non-consensual, 'choice-of- law' provision which needs to be applied in transactions where it is relevant but does not affect the law in general, with respect to other transactions of a similar nature. See also Chan Sek Keong, The Civil Law Ordinance, Section 5 (1-A Reappraisal [1961] MLJ lviiii; Mun Kai Piano Co v Rozario (1962) 28 MLJ Lxxxvii; Rutter, supra n.6 at 181-182. 


\section{PART 2}

\section{IMPLICATIONS OF THE UNITED KINGDOM'S ENTRY INTO THE EU FOR THE FORMER COLONIES AND SINGAPORE, AND THE LATTER'S RESPONSE}

This is perhaps the most significant development, in commercial law terms, since Merdeka because while the scope for the application of English commercial law has been reduced by the enactment of local legislation, UK's entry into the European Community may have made EU law applicable in the former colonies as these are (now) "the laws administered in England.” This problem does not apply to the former Malay States as the cut-off date $7^{\text {th }}$ April 1956 excludes subsequent English commercial law.

Britain had acceded to the 1957 Treaty of Rome, and by enacting the European Communities Act 1972 accepted that EU laws were to be part of the law of the United Kingdom. Lord Denning had put it expressively: "The Treaty is like an incoming tide. It flows into the estuaries and up the rivers. It cannot be held back.” The problem according to sec. 5(2) is that the tide of EU law may if taken literally flow into the Malaysian commercial law regime.

If so the first question that has to be answered is: what are the EU laws? The question of their accessibility is by itself difficult. The advice given to English lawyers is worth repeating: "It must be borne in mind that Community legislation is drafted in several languages and that the different language provisions are all authentic. An interpretation of a provision of Community law thus involves a comparison of different language versions. It must be borne in mind, even when the different language versions are entirely in accord with one another, that community law uses terminology which is peculiar to it. Furthermore, it must be emphasized that legal concepts do not necessarily have the same meaning in Community law and in the law of the various Member States. Finally, every provision of Community law must be placed in its context and interpreted in the light of the provisions of Community law as a whole, regard being had to the objectives thereof and to its state of evolution at the date on which the provision in question is to be applied." ${ }^{34}$

$34 \quad$ CILFITv Ministry of Health [1982] ECR 3415 quoted in Boch, Christine: 'EC Law in the UK.' European Law Series Longman 2000. 
As if accessing and understanding EU law was not enough of a challenge, there is also the problem of harmonizing and ensuring the prevalence of EU law in the event of inconsistency between the two if English law is to be applied today as an English court would. EU laws are to prevail over UK laws in the event of a conflict: "Thus, whatever limitation of its sovereignty Parliament accepted when it enacted the European Communities Act 1972 was entirely voluntary. Under the terms of the Act of 1972 it has always been clear that it is the duty of a United Kingdom court when delivering final judgment, to override any rule of national law found to be in conflict with any directly enforceable rule of Community law." 35

This means that -

i) lawyers in Singapore (and perhaps, the former colonies) had to keep themselves informed of EU law and to understand it; and

ii) lawyers in Singapore (and the former colonies) had to modify English legislation to accord with EU law where this had not been done yet by English courts, and persuade Singapore courts as to the validity of their efforts;

iii) if lawyers in Singapore (and the former colonies) keep citing English cases as their wont, they will have to dissect them between their pure English parts and the EU modified parts;

iv) the people of Singapore (and of the former colonies) particularly their businessmen had to re-gear themselves to meet the requirements of EU law. 


\section{THE SINGAPORE RESPONSE}

Unsurprisingly, Singapore gave up the effort of keeping abreast of EU law. In 1979, Singapore amended ${ }^{36}$ its Civil Law Act to remove EU laws:

After that sec. 5(1) of the Singapore Civil Law Act read:

"Subject to the provisions of this section, in all questions or issues which arise or which have to be decided in Singapore with respect to the law of partnerships, corporations, banks and banking, principal and agents, carriers by sea, land and sea, marine insurance, average, life and fire insurance and with regard to mercantile matters generally, the law with respect to these matters to be administered shall be the same as would be administered in England in the like case at the corresponding period, if such question or issue had arisen or had to be decided in England, unless in any case other provision is or shall be made by any law having force in Singapore.

(2) Nothing in this section shall be taken to introduce into Singapore-

(b) any law enacted after or made in the United Kingdom, whether before or after the commencement of the Civil Law (Amendment no 2) Act 1979-

(i) Giving effect to a treaty or international agreement to which Singapore is not a party; or

(ii) Regulating the exercise of any business or activity by providing for registration, licensing or any other method of control or by the imposition of penalties; and

(c) any provision contained in any Act of Parliament of the United Kingdom where there is a written law in force in Singapore corresponding to that Act.

$36 \quad$ By an earlier amendment, Singapore had restricted English commercial law to the topics listed in its sec 6 of the Civil Law Ordinance. 
(3) For the purposes of this section-

(a) the law of England which is to be administered by virtue of subsection (1) shall be subject to such modifications and adaptations as the circumstances of Singapore may require; and

(b) a written law in force in Singapore shall be regarded as corresponding to an Act of Parliament of the United Kingdom under paragraph (c) of subsection (2) if (notwithstanding that it differs, whether to a small extent or substantially, from that Act) the purpose or purposes of the written law are the same or similar to those of that Act.

With the amendment Singapore solved a number of its English commercial law problems:

i) EU law was eliminated.

ii) it also removed the problem of applying in Singapore, UK legislation relating to the procedures involved in the operation of a business where the same administrative machinery did not exist in Singapore; and

iii) it provided for modification of English commercial law which was not possible under the Civil Law Act.

This did not however solve the problems posed by English commercial law which had now to be applied without modification by EU law which means it does not meet the requirement that it had to be the law administered at the corresponding period in England or the Singapore courts had to do it for the UK courts which still means applying EU law. There was still the problem of identifying, understanding and applying all the ancient and current English commercial law in Singapore whether it had the wherewithal for the observance of such laws.

In 1993, Singapore finally took a drastic step; it repealed its Civil Law Act and introduced the Application of English Law Act 1993. However as the title of the new legislation asserts there was no 
substitution of English commercial legislation with Singapore legislation, instead Singapore simply collected all the UK commercial legislation that it felt it needed in a schedule, modernized the language and also allowed modification.

In the former colonies, sec. 5(2) of the Civil Law Act retains its 1878 vintage wording, and may pose some staggering problems to the legal profession there if taken literally:

1) In addition to the issues and problems already encountered in applying sec. 5(2) as enumerated earlier, lawyers must now keep abreast of every commercial legislative development not only in England but also the EU.

2) Are Malaysian lawyers aware of the complexities of the EU law-making process and the procedure of its courts and system of law reporting, and rules of statutory interpretation applied in the civilian legal system of drafting, ${ }^{37}$ made worse by language problems? ${ }^{38}$

3) If the English law has not been brought in line with EU law, is the Malaysian lawyer expected to harmonize EU law with UK in order to advise on the law as an English court would administer it at present?

4) If not, would he be liable for negligence if he advises according to Malaysian law only without assiduously striving to look for the solution to his client's problem in English / EU law particularly, where it may be more favourable?

5) Malaysian courts have tended to ignore the EU implications of UK law, which is not applying English law as it is in England as sec. $5(2)$ requires. ${ }^{39}$

$37 \quad$ For a good introduction to the complexities from the perspective of an English court which would be the position of a Malaysian court, see Boch, Christine: 'EC Law in the UK'. European Law Series Longman 2000.

$38 \quad$ Supra n. 34.

39 In Smith Kline \& French Laborotories Ltd. v Salim (Malaysia) Sdn 
In the face of the Malaysian Attorney General's ${ }^{40}$ lassitude, the answer may be found in the Federal Constitution.

\section{PART 3}

\section{CONSTITUTIONALITY OF SECTION 5(2) AND THE COMMERCIAL LAW REGIME OF THE FORMER COLONIES}

Is sec. 5(2) of the Civil Law Act 1956 constitutional in the light of Article 44 which declares: "The legislative authority of the Federation shall be vested in a Parliament...." The effect of the article is that a foreign legislature cannot make law for application in Malaysia, only Malaysian legislatures may do so. In keeping, the UK Parliament had to renounce its law-making powers over Malaya when it achieved Independence ${ }^{41}$ and later, over Sabah and Sarawak when they became part of Malaysia. ${ }^{42}$ The assertion of the right of the Malaysian Parliament to make law for Malaysia is too clear to brook any notion of shared or delegated sovereignty in law-making with a foreign legislature.

Sec. 5(2) is valid only to the extent that it allows the application of English commercial law as at $31^{\text {st }}$ Merdeka 1957. UK commercial legislation made after the Constitution had come into force should be disapplied. ${ }^{43}$

\footnotetext{
Bhd [1989] 2 MLJ 380 the court had to consider the UK Patents Act 1977 but said nothing about its effect in Malaysia after any EU modification as in the result it did not apply it at all. He is the chief legal advisor to the government and presumably responsible for legislation which are not administered by any Ministry. Art. 145 (2) Federal Constitution.

41 (UK) Federation of Malaya Independence Act 1957, 5 \& 6 Eliz 2 c 60.

$42 \quad$ (UK) Malaysia Act, 1963; Ch 35 of 1963; The Sabah, Sarawak and Singapore (State Constitutions) order in Council 1963 (S.I.) 1963 No 1493.

43 A delicate term probably invented to fit the EU jurisprudence as 'strike out' or void for inconsistency may be seen as a form of interference with the sovereignty of the EU members.
} 
However no Malaysian court has ruled on Article 44 and its effect on sec. 5 of the Civil Law Act. The opinion expressed here is only the submission of the writer, and taking the effect of Article 44 as moot till a Malaysian court rules on it definitively. There are some reported decisions which involve the post-Constitution application of English lawcommon law and legislation- without taking into account Article 44:

i) In the case of J. M. Wotherspoon \& Co. Ltd. v Henry Agency House $^{44}$ Suffian $\mathrm{J}$ as he then was held that the common law concept of del credere agent applied as there was no provision on it in the then Contracts (Malay States) Ord. 1950. Though the case was decided after the cut-off date under sec. 5(1) of the Civil Law Ord. 1956 for the application of English commercial law in the Malay States, it may be rationalized as a common law concept which had been in existence since even before the cutoff date. The case illustrates the post cut-off date and postConstitution application of a common law concept to supplement rather than derogate from local legislation.

ii) In Thambipillai v Borneo Motors (M) $L t d^{45}$ it was stated: 'The Common Law rules relating to hire purchase do apply in this country by virtue of sec. $3^{46}$ of the Civil Law Ord. but I have grave doubts as to whether the English Statues modifying the common law apply automatically.' per Gill FJ. Is the learned judge stating that only the 'pure' common law applies after the cut-off date in the former Malay States or hinting at the fact that legislation modifying the common law may be postIndependence?

iii) In Innaya $v$ Lombard Acceptance (Malaya) $\mathrm{Ltd}^{47}$ an attempt was made to apply the English Hire Purchase Act 1938 to a hire

$44 \quad$ (1962) 28 MLJ 86.

$45 \quad$ [1970] 1 MLJ 70 at 71 D.

46 This case also illustrates the tendency to refer to the 2 provisions as if they are interchangeable though in this case the subject matter having been correctly identified as hire-purchase, the correct sec would be sec. 5 .

$47 \quad$ [1963] 29 MLJ 30. 
purchase transaction in Penang. This is an instance of sec. 5(2) of the Civil Law Act 1956 being invoked to apply postIndependence a pre-Independence legislation in the former colony. As the UK legislation is pre-Independence, Article 44 is not an issue in this case.

iv) In Low Nai Brothers \&Co ${ }^{48}$ Gill J decided that a provision of the English Companies Act 1947 giving the court a discretionary power in a bankruptcy matter, being part of the mercantile law applied in the former Malay States by virtue of Sec. 5(1) of the Civil Law Act 1956, as the post-Independence Bankruptcy Act 1967 of Malaysia did not have such a provision. This case is interesting for it involves pre-Independence UK legislation applied to add to post-Independence Malaysian legislation against the express exclusion of all UK legislation where there is local legislation. The learned judge seems to have thought that a discretion given under UK legislation may be applied here though in the result did not do so because the advocate did not demonstrate the basis for the exercise of the discretion.

By contrast in Tan Mooi Liang $v$ Lin Soon Seng \& Ors $^{49}$ a majority of the Federal Court of Appeal refused to invoke a provision of the English Partnership Act 1890 to supplement the Contracts (Malay States) Act 1950 though the former was 1956 because the expression 'where other provision' has been made or shall be made. The authority of this case is higher for being an appellate court decision.

v) In Leong Brothers Industries Sdn Bhd v Jerneh Insurance Corp $S d n B h d^{50}$ a case involving claim arising from carriage of goods in breach of a the terms of the marine insurance policy, arising in Penang, the High Court held that the UK Marine Insurance Act 1906 applied by virtue of sec. 5(2) of the Civil Law Act 1956; the case was heard after Independence but as the case involved pre-Independence UK law applied post-

\begin{tabular}{ll}
\hline 48 & [1969]1 MLJ 171. \\
49 & {$[1974] 2$ MLJ p. 60. } \\
50 & {$[1991] 1$ MLJ 102. }
\end{tabular}


Independence, the issue of constitutionality did not arise. Perhaps the only significance of the case is that the UK law was applied in Malaysia without EU modification.

vi) In Heng Long Motor Trading Co. v Osman bin Abdullah ${ }^{51}$ the High Court held that the UK Sale of Goods Act 1979 applied, correcting the lower court which had applied the UK Sale of Goods Act 1893. The lower court's decision is clearly the correct one, if the Constitution had been referred to. The case also illustrates the sledge-hammer solution that English law is where it is applied in domestic transactions which in this case involved a second-car in the boondocks that Sarawak is by comparison with the place of origin of the legislation. The case also illustrates the difficulty of keeping oneself informed of UK legislative activity.

vii) In Smith Kline \& French Laboratories Ltd v Salim (Malaysia) Sdn. Bhd. ${ }^{52}$ the provision in question was similar to sec. 5(2). The Malaysian written law being sec. 6 of the Registration of United Kingdom Patents Act 1951 gives patents registered in Malaysia, the same protection as patents registered in England under its (UK) Patents Act 1977. The patents had been registered in Malaysia by the plaintiffs who also appointed agents in Malaysia and in England from whom the defendant had purchased the drugs in question for re-sale in Malaysia. The plaintiff's case was that the defendant sold the drugs in Malaysia in breach of the plaintiffs' rights. The defendant contended, inter alia, that the plaintiffs' case was based on the UK Patents Act 1977, and that the legislation did not apply in Malaysia because by virtue of sec. 3(1) and sec. 5(1) of the Civil Law Act 1956, the UK legislation could not apply in Malaysia after the cut-off date. The court dismissed this contention on the basis that the action was in fact based on specific legislation and not the Civil Law Act $1956 . .^{33}$

$51 \quad$ [1994] 2 MLJ 456.

$52 \quad$ [1989] 2 MLJ 380.

53 The court also held that patents were not part of the mercantile law and therefore sec. 5 did not apply. 
The court's view was that the plaintiff's right was based on other discrete legislation and not the Civil Law Act 1956 and was therefore not subject to the cut-off date whether it is the Civil Law Act or any other legislation which provides for the application in Malaysia of post-Independence foreign legislation the position is the same.

Article 44 of the Constitution was not referred to the court, and if it was the court may have held that the whole of the 1977 UK Act may not have been strictly binding ${ }^{54}$ even if the defendant had been advised by the agents of the restrictions imposed by the patents on the basis of such parts of it as could be applied. (The trial judge seems to have been concerned only with the practical difficulties of applying foreign law where there is no facility for doing so). ${ }^{55}$

However, the Civil Law Act 1956 is pre-Merdeka. Article 162 states that pre-Merdeka legislation which is inconsistent with the Federal Constitution may be modified to reconcile with the Constitution. Can section 5(2) be made constitutional by altering, or removing those parts of it which are inconsistent with the Constitution as provided by the Constitution itself? Article 44 may be interpreted as allowing the application of foreign legislation to the extent of treating such legislation as a nonbinding source to fill gaps in Malaysian legislation or to supplement local common law on commercial matters. The Constitution does not proscribe foreign law as a source of law; only that a foreign legislature cannot, with the coming into effect of the Constitution, enact laws for Malaysia.

If the provision could be and is modified as pre-Merdeka legislation, it may be expressed in statutory form as:

54 As for the parts of the legislation that is difficult to apply, the judge, Shankar J observed per curiam, relying on Prof. Bartholomew, that: "If it were found that the general provision of such imported legislation is inapplicable in the country the courts have the jurisdiction to strike down such inapplicable law on the principle lex non cogit impossiblia." 55 As for the parts of the legislation that is difficult to apply, the judge, Shankar J observed per curiam, relying on Prof. Bartholomew, that: "If it were found that the general provision of such imported legislation is inapplicable in the country the courts have the jurisdiction to strike down such inapplicable law on the principle lex non cogit impossiblia." 
"In all questions or issues which arise or which have to be decided in the States of Malacca, Penang, Sabah and Sarawak with respect to the matters referred to in subsection (1), save so far as other provision has been made or hereafter be made by any written law in force in those States, the law to be administered shall be the law of England in force as at Merdeka Day, and English legislation on the matters referred to in subsection 1 enacted after that date may be referred to and applied by the courts to the extent that it does not derogate from local legislation and is consistent with the usages of commerce and trade ${ }^{56}$ and to achieve consistency with the law applicable in the other states of Malaysia."

There are post-Merdeka Malaysian legislation which allow the application of foreign law to varying degrees. They do not, however, allow foreign legislation to apply in toto as a binding source of law in Malaysia; only for gaps in Malaysian legislation to be filled or for the courts to be guided by their principles and approaches, and the discretion is with the local courts:

i) The Law Reform (Marriage and Divorce) Act, 1967 (Act 164), by its sec. 47 provides: 'Subject to the provisions contained in this Part, the court shall in all suits and proceedings hereunder act and give relief on principles which in the opinion of the court are, as nearly as may be, conformable to the principles on which the High Court of Justice in England acts and gives relief in matrimonial proceedings.' There is no mention of English legislation here, only principles, and as understood by and at the discretion of Malaysian courts.

ii) Section 5, of the Criminal Procedure Code, amended in 1976, ${ }^{57}$ would seem to be more restrictive: 'As regards matters of criminal

\footnotetext{
$56 \quad$ See Prof. Ahmad Ibrahim, The Civil Law Ordinance in Malaysia [1971] 2 MLJ viii.

$57 \quad$ Criminal Procedure Code (Amendment and Extension) Act 1976 (Act A 324).
} 
procedure for which no special provision has been made by this Code or by any other law for the time being in force the law relating to criminal procedure for the time being in force in England shall be applied so far as there is no conflict or inconsistency with this Code and can be made auxiliary thereto. ${ }^{58}$ Clearly, English law which conflicts or could affect a change to the meaning of the Code is excluded as that would be tantamount to making law for Malaysia; it is essentially for filling gaps.

Obviously, these are not examples of the post-Merdeka application of post-Merdeka English legislation because it is the post-Merdeka Malaysian Parliament which has given permission to apply foreign law but not legislation. These examples serve only to prove that the idea is not alien to the Malaysian legal system as legislation is always countryspecific.

However, as the Constitution refers only to the legislative or law-making authority, the common law it seems is not affected and may be applied in Malaysia, under the Declaratory Theory, as a non-binding source at the discretion of the court to the extent of filling gaps in local legislation where it may fit the framework and purpose of local legislation. ${ }^{59}$

This will, it is submitted, make for an eclectic approach based on the needs of Malaysian commerce and the Malaysian legal system. Malaysian advocates will still be citing English cases whenever they cannot find the answer in local law however, they should be required by the courts to justify it: is the case post 1957?; does it involve any UK law?; does it apply EU law as part of UK law because if it did, EU law may be imported into our legal system without authority. Answering these questions would no doubt tax the research and advocacy skills of Malaysian lawyers. There can be no easy and ready citing of English law as one might confidently do where there is a binding 'source of law' provision.

Perhaps, the most significant result would be that as the UK enacted the European Communities Act only in 1972, well after the

Sec. 5 Criminal Procedure Code. MLJ 86. 
Federal Constitution had come into force EU law cannot apply in Malaysia via English commercial legislation even as the law of the "corresponding period.'

If it is accepted that it is unconstitutional and invalid to apply in any part of Malaysia, the post-Independence commercial legislation of England as binding law, the consequence will not be as drastic as feared at one time- a gaping legal vacuum into which the commercial life of the nation will collapse and disappear. Nothing of the kind happened in the Malay States after $7^{\text {th }}$ April $1956^{60}$ and the continued application of English legislation may be rationalized as a non-binding source of law.

Malaysian courts may still, as they have in the past, take on board new types of commercial transactions as found in imported standard forms on which there is no Malaysian law, which makes for private, indirect and piecemeal importation of commercial law ${ }^{61}$ though they are premised on the laws of the 'jurisdiction of origin' of the standard form applying. In such cases, the decision of the court may not constitute Malaysian commercial law in the general sense but a specific Malaysian law applicable to all transactions based on the standard form interpreted by the decision. ${ }^{62}$

It will not prevent successive waves of returning law graduates depositing on Malaysian shores the latest English commercial law ideas when these are incorporated into their clients' contracts. Where there is a foreign element in the transaction, parties may have 'applicable law' provisions as they do now.

It appears that if Article 44 is applied, as intended to modify post-Merdeka English commercial law, the resulting process would be

60 It would appear that in the absence of Malaysian legislation and without a statutory basis for the continued application, the Malaysian legal profession including judges followed the example or their colonial predecessors and applied English case-law by force of habit!

61 For example, the concept of the 'turnkey' contract, a construction innovation, was imported into Malaysia and applied as understood by construction personnel before it was legally defined, and interpreted by a Malaysian court; it is understood that there was no authority on it anywhere in the common law world before it: High Mark (M) Sdn. Bhd. v Patco Malaysia Sdn.Bhd. 28 BLR at 133. See supra n. 33. Supra n. 33. 
eclectic and controlled by Malaysian judges who may be expected to know more about local circumstances and people, and about innovations in commerce where enacted law had not caught up, and also reduce the need for 'outsourcing' and adaptation.

An interesting question, not proposed to be examined any further partly because of its diminishing significance, if any, is the gap between Merdeka Day and $5^{\text {th }}$ April 1956 in the application of English commercial legislation. Does this violate the promise of equal protection of the law under Art. 8? By the operation of Article 44, the whole country, it seems, achieves a common cut-off date: $31^{\text {st }}$ August 1957. In the case of the former Malay States, the specific cut-off date - $7^{\text {th }}$ April 1956 - had excluded English commercial legislation, and between the former Malay States and the former colonies there is only a gap of slightly more than year in the application of English law. With the enactment of local legislation extended to both parts of the country ${ }^{63}$ e.g. the Sale of Goods Act 1957 has been extended to Penang and Malacca by the Sale of Goods (Amendment and Extension) Act 1990;64 the gap is expected to narrow, and be relegated to history as a stage in the development of the Malaysian commercial law regime.

\section{CONCLUSIONS AND SUMMARY}

Starting from a common base, like many things about them, Singapore and Malaysia shared the same provision, appeared to be going separately, and then converged along similar lines:

(i) Singapore carefully crafted its sec. 5 to accommodate its needs to solve the problems caused by the changes in English law.

(ii) Malaysian did nothing. Indifferently rather than as a conscious measure, it left matters to the operation of its Constitution.

\footnotetext{
$63 \quad$ By the operation of the Malaysia Act 1963 the partnership law of Sarawak and the arbitration law of Sabah have been extended to the whole country.

64 With effect from $23^{\text {rd }}$ February 1990; this makes it unnecessary to refer to the English law of sale of goods.
} 
(iii) Fortuitously for Malaysia by the operation of its Constitution, if a court rules as submitted, and in Singapore as a result of its Parliament's efforts, the English commercial legislation of both territories converge:

a) They have both eliminated EU law;

b) They have both reduced English commercial legislation to those which had been applied during the colonial period;

c) Singapore may have reduced its difficulties by providing for modification of the UK legislation and Malaysia though having to apply it in all its original stiffness ${ }^{65}$ may reduce its difficulties by using them as a non-binding source of law;

d) Malaysia may enjoy greater clarity and certainty as to the pre-Independence UK legislation applicable in Malaysia as a result of the identification by Singapore of the colonial commercial legislation in the schedule to its Application of English Law Act. (This is, of course, in addition to those spelt out in the provisions applicable to Sarawak). ${ }^{66}$

\section{External developments that will have an indirect or long-term effect are:}

- $\quad$ Singapore's repeal in 1993 of sec. 5 of its Civil Law Act and enactment of the Application of English Law Act so that except

65 Sarawak has for long had this comfort of modification as seen in Sec. 3(ii) of the Civil Law Act extended from its Application of Laws Ordinance, "the Acts of Parliament of the United Kingdom....continue in force in Sarawak with such formal alterations and amendments as may be necessary to make the same applicable to the circumstances of Sarawak and, in particular, subject to the modifications set out in....schedule."

66 Sec. 3(ii) Civil Law Act 1956 and Second Schedule. 
for certain, identified and gazetted English legislation no others apply. ${ }^{67}$

- The Islamisation of British colonial-era legislation in certain Muslim countries- Pakistan, ${ }^{68}$ Nigeria and Sudan.

- A development that has a greater homogenizing effect on commercial law than even colonization is the globalization phenomenon carried out by the WTO.

- $\quad$ Malaysia's membership of the Asean Free Trade Association (AFTA) which may ultimately lead to the standardization of its commercial laws with those of the other ASEAN countries; 7 of the 10 AFTA countries are civilian law system countries and have codes $^{69}$ on commercial law.

\section{PART 4}

\section{ISLAMIC COMMERCIAL LAW VALUES AND ETHICS ${ }^{70}$}

If the English could properly expect that their commercial law as applied in England and in up- to- the minute form should apply in Malaysia, then Muslim Malaysia may try to ensure that its commercial law does not jar

Sec. 4(2) and First Schedule Application of English Law Act 1993.

68 See Islamization of Laws in Pakistan by Dr Mohd. Amin (1989) Niaz Ahmed Sang-e-Meel Publications, Lahore. Pakistan has Islamised the following commercial laws: Contract Act; Partnership Act; Negotiable Instruments Act; Companies Act; Transfer of Property Act; Sale of Goods Act; and Tenancy Act See also 'The Administration of Islamic Law in Pakistan' by Nazir Ahmad Bhatti in The Administration of Islamic Law edts: Ahmad Mohamed Ibrahim \& Abdul Monir Yaacob IKIM 1997.

$69 \quad$ Eg. Civil and Commercial Code of Thailand.

70 See C.G. Weeramantry, 'Islamic Jurisprudence; An International Perspective;' Some Basic Islamic Legal Ideas: The Notion of Fair Contract, The Notion of Commercial Integrity, The Notion of Freedom from Usury etc., The Other Press, 2001. 
its inhabitants' sense of right and wrong, ${ }^{71}$ and commercial law development is not dictated by the application of the standard forms of greedy businessmen and their expensive lawyers.

Always careful, and circumspect particularly of the need to assure non-Muslims and the need to maintain legal continuity and of the dangers of precipitate change, Prof. Ahmad did not advocate wholesale, overnight repeal of existing law and its replacement by Islamic law. He preferred the legislative process ${ }^{72}$ of Islamisation rather than leaving matters to the court.

As suggested earlier, Malaysian law-makers may also refer to Islamised versions of British colonial legislation on commercial subjects ${ }^{73}$ which have been made in Pakistan, Nigeria and Sudan, for guidance. Malaysia has already succeeded in introducing Islamic commercial transactions in the form of Islamic banking by means of the legislative process so that it now sits comfortably with ribawi banking.

Prof. Ahmad Ibrahim seems to have had a similar idea as Lord Atkin. ${ }^{74}$ When he suggested that sec.'s 17, 19 and 23 of the Contracts Act 1957 (and the Illustrations to these sections) and similar provisions in the Sale of Goods Act 1957 be amended to remove the English law concept of caveat emptor (or 'let the buyer beware') and to replace it with the Islamic ethic in transactions that the seller is put under a positive duty to disclose to the purchaser the defects in his goods (not unknown

$71 \quad$ Acknowledged in sec. 3 of the Civil Law Act 1956 as the basis for modification of the common law in all non-commercial matters.

72 The process of Islamisation of laws in Pakistan is carried out by its Federal Shariat Court at the instance of parties challenging the validity of unIslamic laws in litigation which is makes for a less systematic manner of Islamisation as the subject and pace of Islamisation is left to the chance of it being raised by private parties, and not initiated by the political executive and allows only a reduced role to the legislature. Article 203 Constitution of the Islamic Republic of Pakistan.

73 Supra, n.66.

74 Lord Atkin in the famous case of Donoghue $v$ Stevenson looked to the Bible-'Love thy neighbour'- to found his 'neighbour' principle to establish a duty of care between the manufacturer and the ultimate consumer bypassing the intervening retailer in order to get around the 'direct-relationship-contractual' paradigm that had stood in the way until then. 
to English law; the principle of caveat venditor or 'the seller beware'). ${ }^{75}$ He has also suggested that Malaysia should restore the Mejelle, ${ }^{76}$ which was applied in Johor in 1914 as the Majallah Ahkam Johor, at least for transactions between Muslims (and with, and between non-Muslims, at their option, much like Islamic banking), and for trade between Muslim nations. ${ }^{77}$ As codes $^{78}$ tend to have a list of objects and purposes, ${ }^{79}$ the adoption of such legislation would enable Malaysia to have a list of the ethics and values of Islam as applied to commerce ${ }^{80}$ to serve as the guiding principles of all transactions.

Specifically, with respect to sec. 5(2) he had suggested the adoption of a commercial code modelled on the Egyptian Commercial Code of 1948. It provided a role for Islamic law: "In the absence of an express provision, the judge shall follow the rules of custom; if they do not exist, the principles of Islamic Law and if they in turn do not exist, he shall follow the principles of natural law and equity." 11

\footnotetext{
75 'Recent Developments in the Administration of Islamic law in Malaysia' in The Administration of Islamic Law in Malaysia, supra n. 69. Majallah al-Ahkam Al-Adliya (The Book of Rules of Justice) a complete Islamic Civil (commercial) Law which came into existence in Turkey in 1869, and is the law applied in commercial matters, both domestic and international, mainly with the West, and in Malaysia in 1901. It is the legal framework sustaining the entrepot economy of the United Arab Emirates which promulgated its Mejelle-based Civil Code in 1985 A rendition into modern English has been made by Prof. Ballantyre and published in the Arab Law Quarterly. For an account see Prof. Ballantyre's 'Note on the New Commercial Code of Bahrain' Arab Law Quarterly 2 (1987) 352.

Malaysia, as a member of Asean and AFTA, (6 of whose 10 members belong to Civil Law system countries), may also consider the Thai Civil and Commercial Code. With its 400-odd provisions written in Thai and accessible and comprehensible to its people; and comprehensive and modern enough to reduce the need for other laws, and written in the broad brushstrokes style of Civil Law System legislation, it has enabled Thailand to conduct its domestic and international trade and commerce, and industrialize, with apparently less uncertainty and difficulty.

79 Book 1 General Principles, Thai Civil and Commercial Code.

$80 \quad$ Supran.72.

81 Prof. Ahmad Ibrahim ‘The Civil Law Ordinance in Malaysia’ [1971] 2 MLJ lviii at p. lxi; similarly, the Commercial Code of Bahrain (Decree Law 7/1987).
} 
Prof. Ahmad clearly preferred the legislative process: working within the framework of the Constitution; amending existing written laws and introducing new ones, which would ensure the stability of the legal system; while retaining the all-important common law system characteristics of the adversarial litigation, so that the Malaysian commercial law regime remains recognisably inclusive and civil but not secular. 